\title{
Investigating Predictive Factors of Power of the Theory Planned Behavior (TPB) on the Prevention of Urinary Tract Infection in Mothers Under 2 Years of Age
}

\author{
Zahra Ahmadi ${ }^{1}$, Mohsen Shamsi ${ }^{2 *}$, Nasrin Roozbahani ${ }^{3}$, Rahmatalah Moradzadeh ${ }^{4}$
}

1. MSc. Student, Student Research Committee, Department of Health Education and Health Promotion, School of Health, Arak University of Medical Sciences, Arak, Iran

2. Associate Professor, Department of Health Education and Health Promotion, School of Health, Arak University of Medical Sciences, Arak, Iran

3. Assistant Professor, Department of Health Education and Health Promotion, School of Health, Arak University of Medical Sciences, Arak, Iran

4. Assistant Professor, Department of Epidmiology, School of Health, Arak University of Medical Sciences, Arak, Iran

\section{Article Info \\ Received: $\quad 2018 / 08 / 26$ \\ Accepted: $\quad 2018 / 12 / 08$ \\ Published Online: 2019/03/22}

DOI: $10.30699 /$ sjhnmf.27.2.133

Original Article

Use your device to scan and read the article online

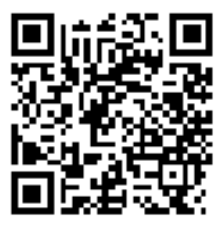

\section{Abstract}

Introduction: One of the most important problems in childhood is urinary tract infections, which can lead to permanent damage to the kidneys. The purpose of this study was to measure the constructs of the theory of planned behavior regarding the preventive behaviors of urinary tract infection in mothers with a dughter under two years of age.

Methods: This is a cross-sectional and analytical study that was carried out on 280 mothers of girls under the age of two years who referred to health centers and were randomly selected. The data was collected by a researcher-made questionnaire validity and reliability of which were confirmed. The questionnaire included demographic characteristics of the mother, dimensions of the planned behavioral model and maternal duty checklist. Finally, the data were analyzed using SPSS 20, Pearson correlation and linear regression tests.

Results: Mean and standard deviation of attitude score (3.87 \pm 0.37$)$, subjective norm (4.09 \pm 0.49$)$, perceived behavior control $(4.32 \pm 0.47)$, behavioral intention $(4.59 \pm 0.47)$ performance $(2.78 \pm 0.58)$ and knowledge $(0.62 \pm 0.1)$ was observed. In regression analysis, variables of knowledge and intention to behave, predicted a total of $15 \%\left(\mathrm{R}^{2}=0.16, \mathrm{~B}=1.342, P=0.001\right)$ of behavioral change.

Conclusion: According to the results of the study, in designing educational interventions, the awareness and structure of behavioral intention should be considered as the most important predictor of mothers' behavior.

Keywords: Planned Behavioral Theory, Urinary Tract Infection, Mother
Corresponding Information

Mohsen Shamsi, Associate Professor, Department of Health Education and Health Promotion, School of Health, Arak University of Medical Sciences, Arak, Iran. Email: dr.shamsi@arakmu.ac.ir

Copyright (C) 2019, This is an original open-access article distributed under the terms of the Creative Commons Attribution-noncommercial 4.0 International License which permits copy and redistribute of the material just in noncommercial usages with proper citation. 


\title{
مجلهُ مراقبت يرستارى و مامايى ابن سينا - شايا الكترونيك: بو \\ مقالة يزوهشى ابن سينا
}

سنجش سازههاى تئورى رفتار برنامهريزى شده (TPB) در خصوص رفتارهاى بيشغيرى كننده

از عفونت ادرارى در مادران داراى دختر زير ب سال

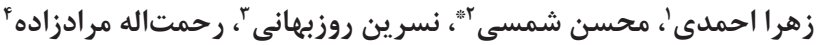

\begin{abstract}
ا. دانشجوى كارشناسى ارشد، كميتهٔ تحقيقات دانشجويى، گروه آموزش بهداشت و ارتقاى سلامت، دانشكدة بهداشت، دانشگاه علوم يزشكى

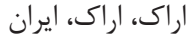

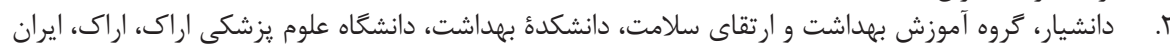

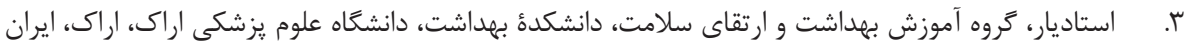

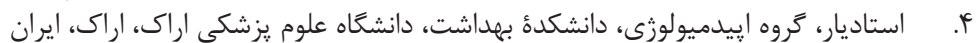

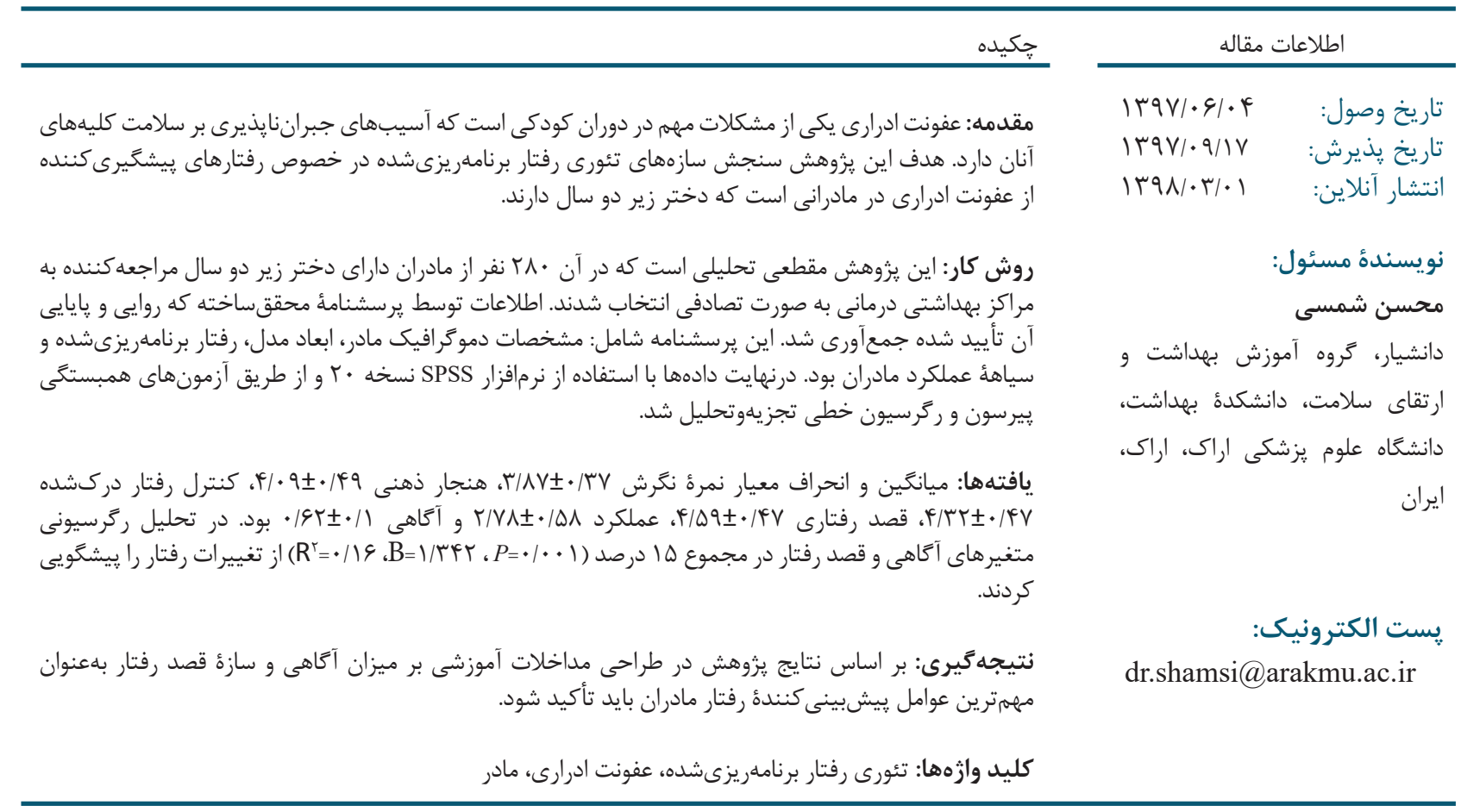

مقدمه

مراقبان اصلى كودكان (مادران) ضرروى است [9]. آموزش يكى از

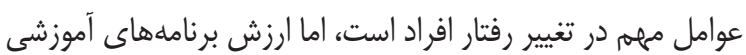
بهداشت به ميزان اثربخشى اين برنامهها بستخى دارد و اثربخشى

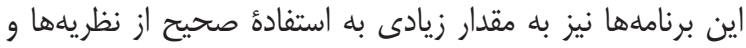

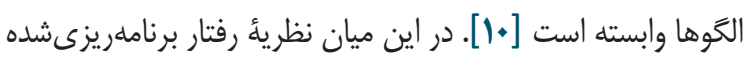
يكى از نظريههاى مهم در آموزش رفتارهاى بهداشتى است كه بر استر

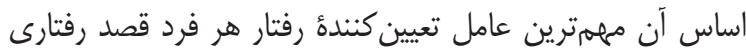

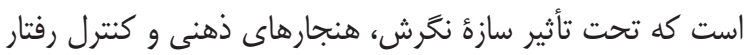

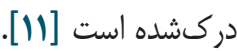

كاربرد نظرئُ رفتار برنامهريزى شده براى ييشيينى و درى

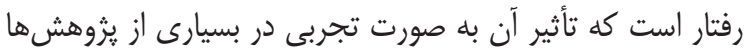

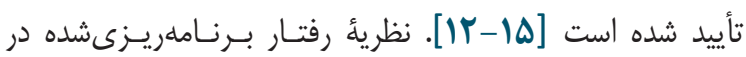
تشخيص و درى عـوامل محيطى و فـردى مـؤثر بـر رفتــار
سالانه ميليونها نفر در جهان به صورت سريايى يا بسترىشدن در بيمارستان به عفونتهاى ادرارى مبتلا مىشوند. طبق آمار

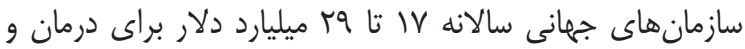
بهبودى عفونتهاى بيمارستانى هزينه مى شود كه از اين مبلغ وساك درصد مربوط به هز ينههاى ايجادشده ناشى از عفونت ادرارى است

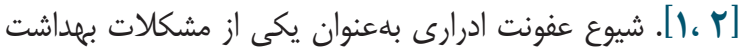

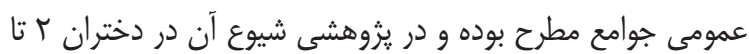

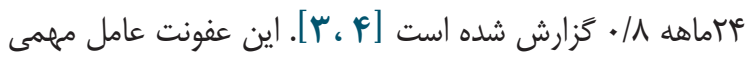
در ايجاد اسكار و تخريب ييشروندهٔ ساختمان كليهها، نارسايى مزمن كليه، اختالال رشد، سنگَهاى ادرارى و هيبيرتانسيون در

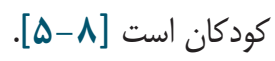

با درنظرداشتن اهميت رفتارهاى بهداشتى در ابتلا به بيمارىها

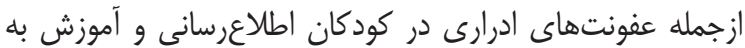


نمونه كيرى به صورت تصادفى انتخاب شد (مجموعاً م مركز) و در مرحلئ دوم در هر مركز، با توجه به حجم نمونئ اختصاصدادهشيده

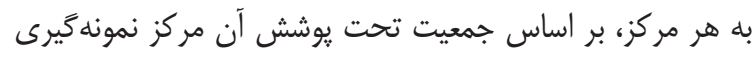
به صورت تصادفى ساده، بر اساس شمارة يروندة بهداشتى خانوار موجود در مراكز، اهداف يزوهش و معيارهاى ورود •ب نم نمونه

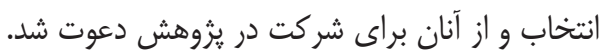

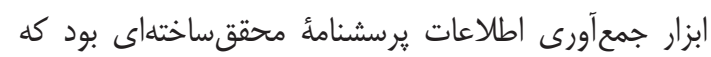

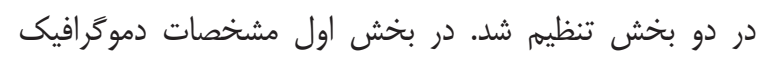
مادر و كودك، شامل: سن كودى و مادر، سابقه ابتلاى فرزند به

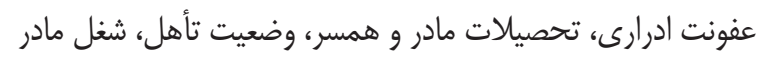

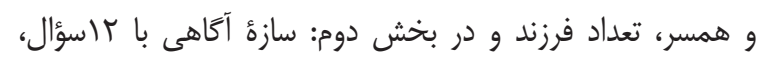
سازءٔ نخرش با عأ سؤال، سازءٔ هنجارهاى انتزاعى با 9 سؤال،

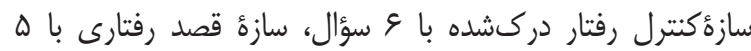

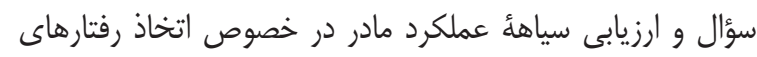

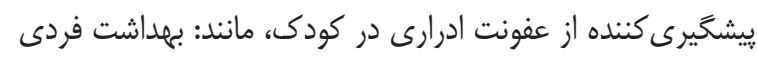

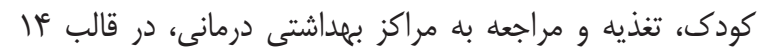

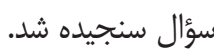

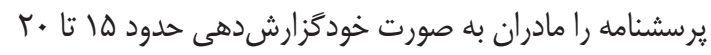

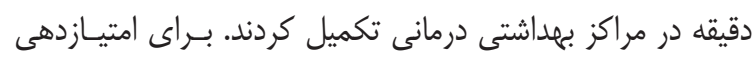

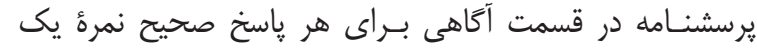

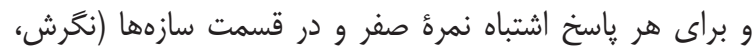
هنجارهاى ذهنى، كنترل رفتار دركشده و قصد رفتارى) امتيازها با نال

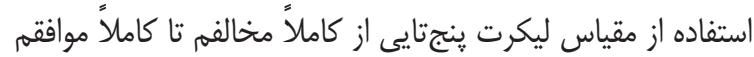

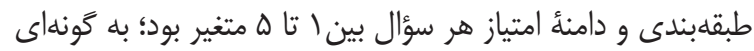

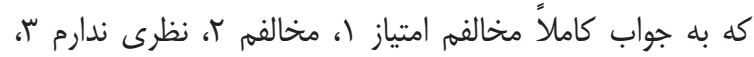

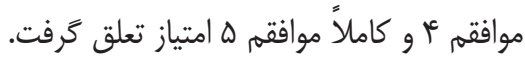
در قسمت سياهئ عملكرد نيز بر اساس رفتار مادر در خصوص يِيشخيرى از عفونت ادرارى در كودى امتياز هر سؤال بين صفر تا

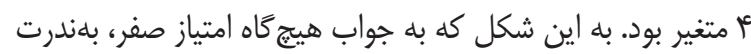

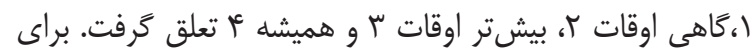
سنجش روايى يرسشنامه از شيؤ روايى محتوايى استفاده شد. به إه

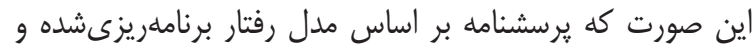

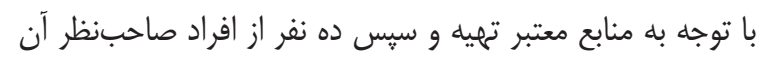

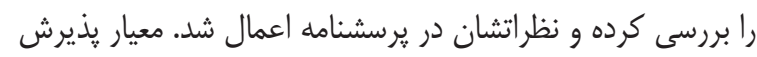

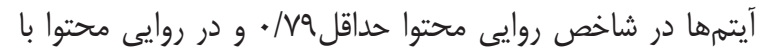

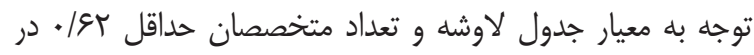

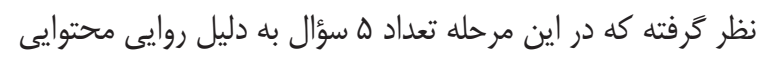
يإيين حذف و نهايتاً روايى آن تأييد شد.

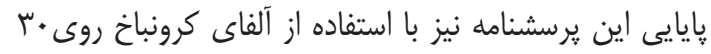
نفر از مادرانى كه از نظر مشخصات دموًرافيك مشابه جمعيت

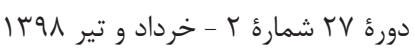

استفـاده مىشود. در ايـن نظـريه علاوه بـر رفتـار مستقيم فـرد

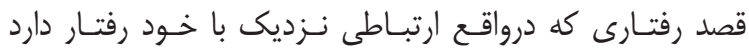

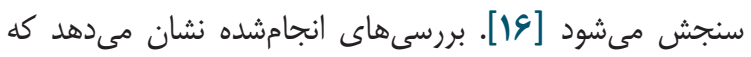
يخوهشهاى اندكى در زمينهُ تأثير مداخلات آموزشى بر مادران

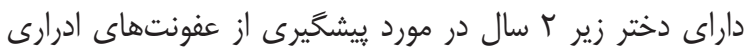

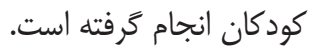

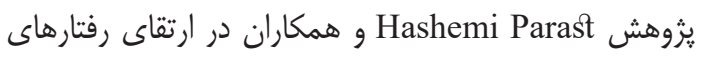
ييشگيرى كننده از عفونت ادرارى با استفاده از الكوى اعتقاد

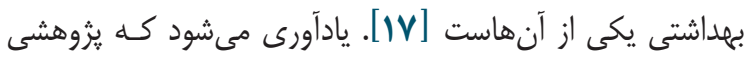

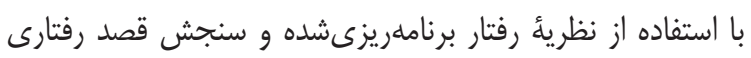

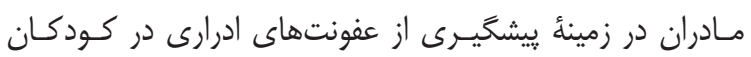
در ايران يافت نشد. در اين يثوهش از دلايل انتخاب تئورى رفتار

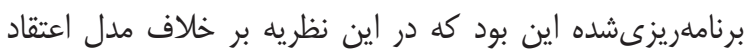

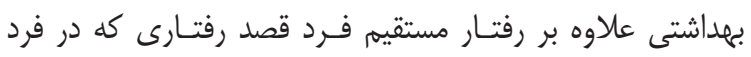

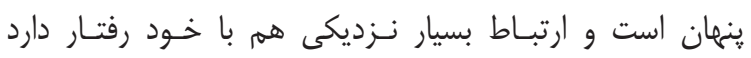

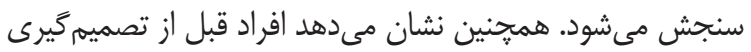
براى درگيرشدن در هر گونه رفتار مشخص، مسائل ييش رويشان

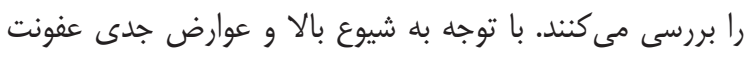

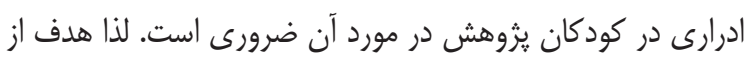

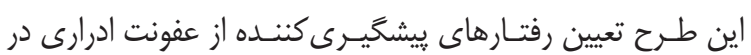

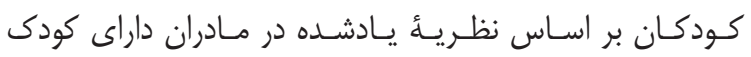

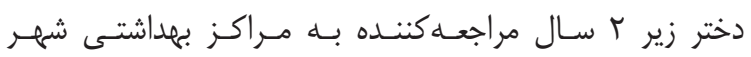

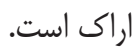

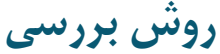

اين يزوهش مقطعى بر •r نفر از مادران مراجعلكنتده به مراكز

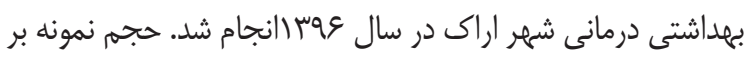

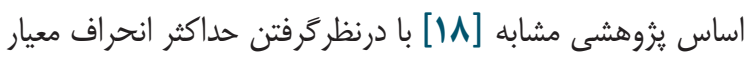

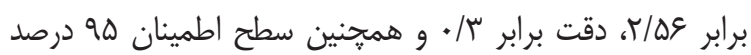

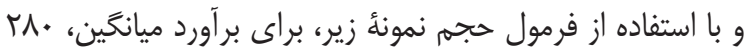

$$
\frac{Z_{1-\frac{\alpha}{2}}^{2} \times \sigma}{d^{2}}
$$

معيار ورود به يزوهش مادرانى بودند كه علاوه بر داشتن حداقل سواد خواندن و نوشتن فرزند دختر زير دو سالى نيز داشتند

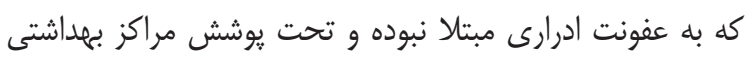
بودند. همجنين معيار خروج از يزوهش نيز تمايلنداشتن مادر براى

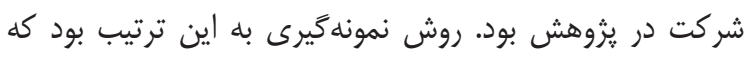
در مرحلئ اول بر اساس جهت دهاى جغر افيايى شهر اراك به به يهار قسمت تقسيه و از هر قسمت دو مركز بهداشتى درمانى براى 


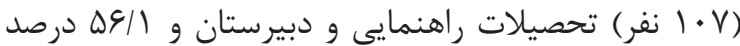
I ا نحصيلات دانشخاهى داشتند. IVV) نفر ) از كل شركت كنند

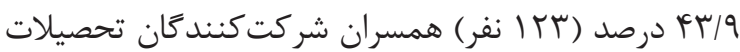
در حد راهنمايى و دبيرستان و •ه درصد (· fl نفر) از آنها تحصيلات دانشخاهى داشتند.

نتايج مرتبط با سازههاى تئورى رفتار برنامهريزىشده داتيند در اين يزوهش در جدول r آمده است. با توجـه به اينكـهـ تـوزيـع دادههــا با استفـاده از آزمــون

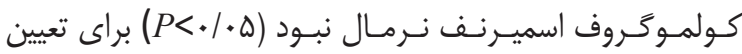

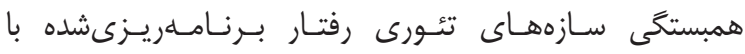

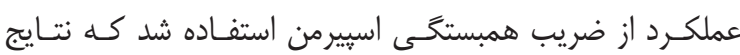
آن در جـدول ب آمده است. در اين يزوهش بين عملكرد مادران و همة سازههاى تئورى رفتار برناملريزى شده با استفاده از آزمون اسبيرمن همبستخى مثبت و معنى دارى و البته در حلد ضعيف وجود داشت . مدل رگرسيون خطى نهايى نشان مىدهد كه به ازاى هر يك واحد افزايش نمره عملكرد مادران نمره آكاهى و

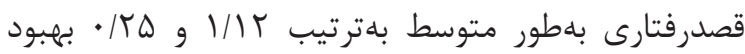
يافته است. از طرف ديخر رابطة خطى منفى بين عملكرد مادران و نداشتن سابقهُ عفونت ادرارى در فرزندان وجود داردي. به اين صورت كه نداشتن سابقهُ عفونت ادرارى در فرزندان

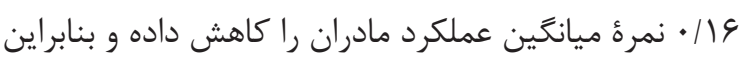
داشتن سابقهُ عفونت ادرارى در فرزندان تأثير معنى دارى روى مي ماني عملكرد مادران داشته است. با توجه به نتايج اين يزوهش آكاهى و قصد رفتار مهمترين سازههاى ييشبينى كننده تئورى رفتار برناملريزىشده است و بلهطوركلى سازههاى تئورى رفتار برنامهريزىشده (آكاهى و قصد رفتارى) و نداشتن سابقه عفونت ادرارى در فرزندان زيشگَويى كننده

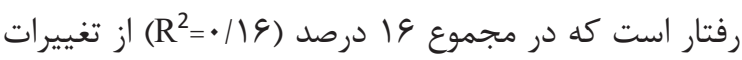

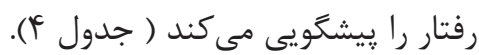

اين يزوهش بودند سنجيده شد. نتايج همسانى درونى با استفاده از ضرايب آلفاى كرونبـاخ نشـان مىدهد كه همـأه ضرايب مطلوب و

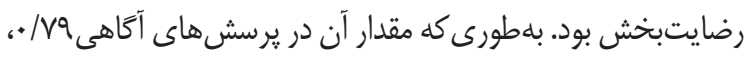

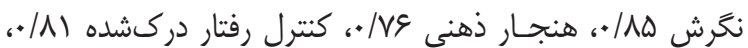

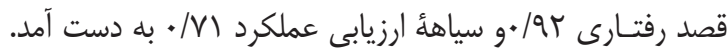
يس از اصلاح يرسشها يرسشنامة نهايى تدوين و براى

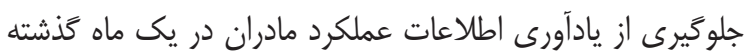

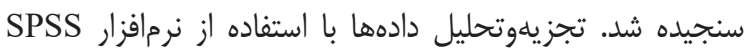
نسخه سب و با كمك آمار توصيفى (ميانخين و انحراف معيار) و آمار تحليلى (ضريب همبستخى اسييرمن) انجام و براى تعيين

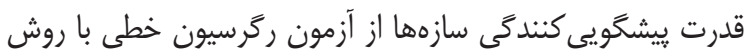

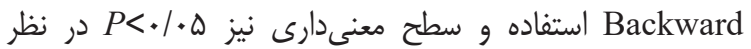
گرفته شد. در اين يُوهش براى رعايت اصول اخلاقى در يزوهش ضمن اخذ رضايت مادران براى شركت در يثوهش توضيحات لازم دربارهٔ هدف يُوهش، نحوه اجراى آن و محرمانهماندن اطلاعات به مادران ارائه و قبل از اجرا نيز كد اخلاقى يزوهش به شماره

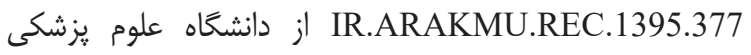

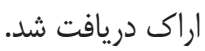

\section{بافتهها}

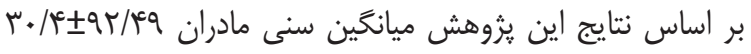

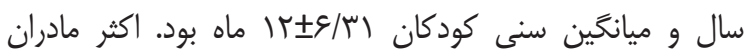
خانهدار ( (1 درصد)، با تحصيلات دانشگاهى ( / /

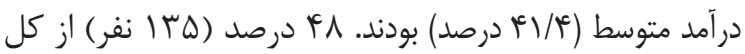
شركت كنند نفر) همسران شركت كنندگان تحصيلات در حد راهنمايى و دبيرستان و •ه درصد (•l|l نفر) از آنها تحصيلات دانشخاهى داشتند. ساير مشخصات دموگرافيك جمعيت اين يزوهش در جدول ا آمده است.

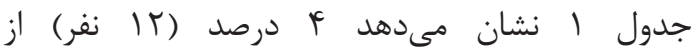
شركت كنند كان سواد خواندن و نوشتن ابتدايى و ^ץ درصد

جدول ا. مشخصات دموكر افيك جمعيت مورد يزوهش

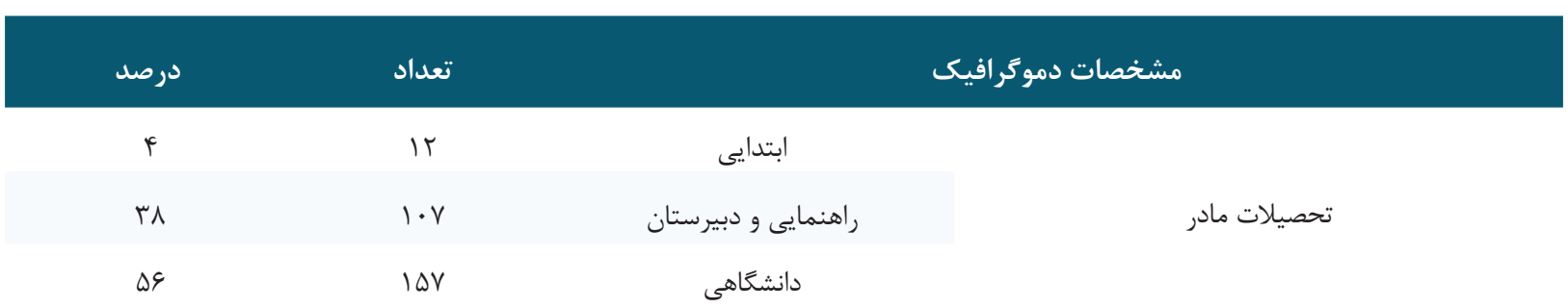




\begin{tabular}{|c|c|c|c|}
\hline 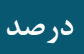 & 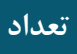 & \multicolumn{2}{|c|}{ مشخصات دموتر افيك } \\
\hline $1 \cdot / V$ & r. & بله & \multirow{3}{*}{ سابقة ابتلا به عفونت ادرارى در فرزندان خانواده } \\
\hline$V V / \Delta$ & TIV & 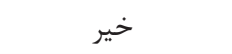 & \\
\hline $\mathrm{V} / \mathrm{Q}$ & YI & نمى داند & \\
\hline$r / T$ & 9 & 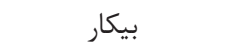 & \\
\hline $1 / 19$ & QT & 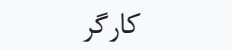 & \\
\hline$r \Delta / \uparrow$ & 99 & آزاد & \\
\hline$r \omega / \uparrow$ & 99 & 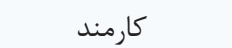 & شغل همسر \\
\hline $1 / 1$ & r & كارمند عالى رتبه & \\
\hline$\cdot / 4$ & 1 & بازنشسته & \\
\hline$\Delta$ & If & 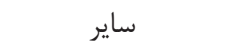 & \\
\hline $1 / 1$ & r & 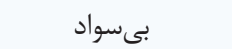 & \\
\hline$r / 9$ & 1. & 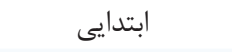 & \\
\hline$f r / q$ & Tr & راهنمايى و دبيرستان & \\
\hline$\Delta \cdot / \cdot$ & If. & دانشعاهى & \\
\hline$\forall \in / F$ & $\pi$. & سه نفر & \\
\hline $49 / 1$ & $1 \% 9$ & جهارنفر & \\
\hline$\Delta / V$ & 19 & ينج نفر & ت تعداد اعضاى خانواده \\
\hline $1 / 4$ & r & 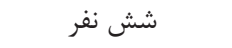 & \\
\hline$\cdot / k^{k}$ & 1 & هفت نف & \\
\hline
\end{tabular}

جدول r. ميانگين نمره سازههاى تئورى رفتار برنامهريزىشده و عملكرد مادران در خصوص رفتار هاى تغذيهاى ييشگيرى كننده

$$
\text { از عفونت ادرارى كودكان دختر كمتر از دو سال }
$$

\begin{tabular}{|c|c|c|c|}
\hline حداكثر & حداقل & ميانَيندانحراف معيار & متغير \\
\hline$r / 9 r$ & r/gF & $r / \Lambda V \pm \cdot / r V$ & 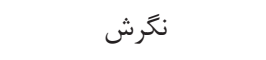 \\
\hline$\Delta$ & T/VA & $4 / \cdot q \pm \cdot / 4 q$ & هنجارهاى ذهنى \\
\hline$\Delta$ & T/IV & F/TTE./FV & كنترل رفتارى دركشده \\
\hline$\Delta$ & r/^৭ & $F / \Delta q \pm \cdot / \& V$ & قصد رفتارى \\
\hline r & .19 & $r / V \wedge \pm \cdot / \Delta \Lambda$ & عملكرد \\
\hline 1 & $\cdot 11$ & $\cdot \mid 9 T \pm \cdot 11$ & آكاهى \\
\hline
\end{tabular}


جدول ץ. همبستگى عملكرد مادران در خصوص يِيشَيرى از عفونت ادرارى دختران زير دوسال با سازههاى تئورى رفتار برنامهريزىشده با استفاده از آزمون اسيِيرمن

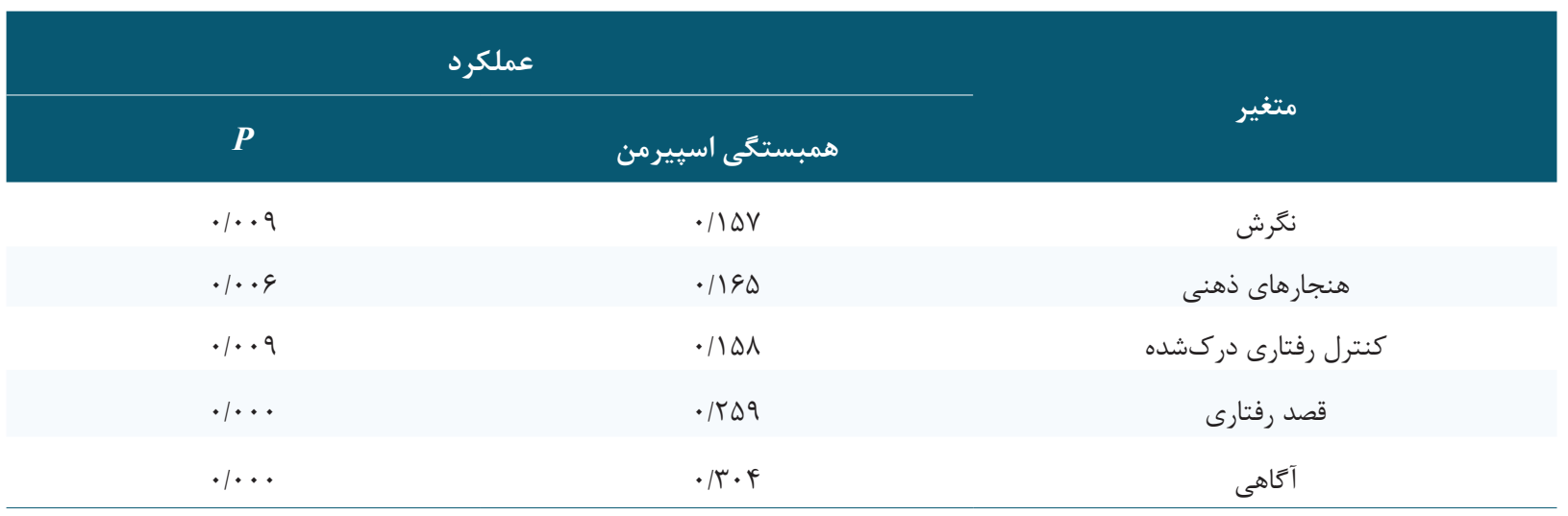

جدول F. تحليل رَّرسيون سازههاى يِيشَويى كنندهُ عملكرد مادران در زمينه يِيشعيرى از عفونت ادرارى كودى

\begin{tabular}{|c|c|c|c|c|c|c|}
\hline ضعديب تعيين & $\begin{array}{c}\text { ضريب تعيين } \\
\left(\mathbf{R}^{2}\right)\end{array}$ & $\begin{array}{c}\text { معنادارى } \\
(P)\end{array}$ & $\begin{array}{c}\text { آزمون مقدار } \\
\text { (t) }\end{array}$ & $\begin{array}{c}\text { ضريب استاندارد } \\
\text { (Beta) }\end{array}$ & غير ضراستاندارد (B) غ & ميشير هين \\
\hline \multirow{4}{*}{.1199} & \multirow{4}{*}{$\cdot|4| 1$} & $<\cdot|\cdot \cdot|$ & $r / 099$ & - & I/MFT & مقدار ثابت \\
\hline & & $<\cdot|\cdots \cdot|$ & F/19९ & - /TAV & $1 / 1 \cdot r$ & آَاهى \\
\hline & & $<\cdot / \cdots \cdot \mid$ & rוT & .1190 & $\cdot / r r V$ & قصد رفتارى \\
\hline & & $\cdot / \cdot r$ & $-Y / / \Delta \Delta$ & . / Tr & $-\cdot / 19 q$ & سفونت ادرارى ابتلا به \\
\hline
\end{tabular}

در گروههاى يزوهش باشد. بلهُونهاى كه در اين يثوهش مادران داراى دختر زير دو سال مد نظر بودهاند و به دليل سن كم كودكان

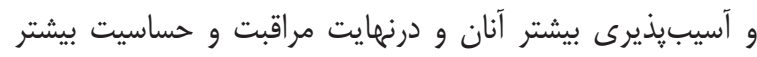
مادران نسبت به سلامت آنان باعث شد كه مادران در خصوص رفتارهاى مراقبتى كودكان خود اطلاعات بيشترى كسب كنند. ضمن اين كه ساير متغيرهاى دموگرافيكى نمونههاى اين يزوهش در هر دو يثوهش در اين خصوص تأثير گذار است. در اين يزوهش نخرش مادران در خصوص ييشخَيرى از عفونت

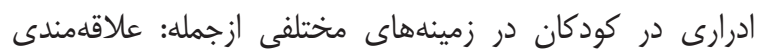
به انجام رفتارهاى ييشخَيرى، وخامت عوارض ابتلا و ارزشيابى

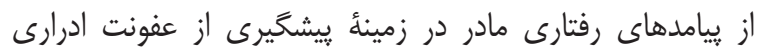

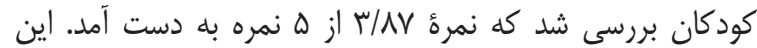
مقدار نخرش بالاتر از متوسط مادران را نشان مىدهد. با اين وجود آموزش مادران در خصوص ييامدها و نتايج انجام رفتارهاى مراقبتى مانى كودكان در اين زمينه با توجه به اهميت موضوع اين يافته همرخوان

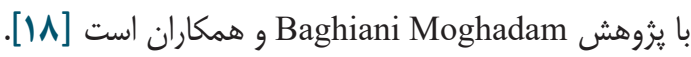
در اين يثوهش ميانخين نمره هنجارهاى ذهنى مادران در

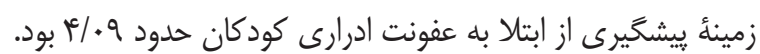

در اين يثوهش ميانكين نمره آَّاهى مادران در خصوص داشتن

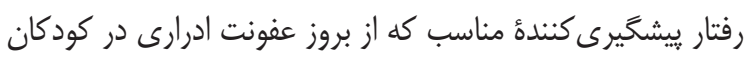

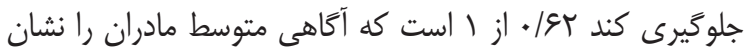
مىدهد. همجنين آكَاهى مادران در زمينأ شناخت عفونت ادرارى مئ كودكان، علائم عفونت سيستم ادرارى مربوط به نوزادان و كودكان إن مئن زير دو سال، انجام آزمايش ادرار براى ييشحَيرى از عفونت ادارى در همة كودكان، آكاهى مادر در زمينأ تأثير تغذيه با شير مادر در شيرخواران به جاى شير خشك در ييشخيرى از عفونت ادرارى

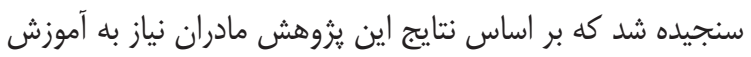
بيشترى در اين زمينهها دارند. و و همكاران يزوهشى توصيفى تحليلى با عنوان لابررسى رفتارهاى ييشگيرى كننده از عفونت ادرارى بر اساس الخوى اعتقاد بهداشتى" در يسا نفر از مادران

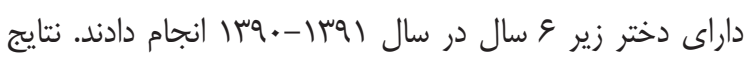
نشان داد نمرهُ آكاهى در عج درصد از نمونهها در سطح متوسط و

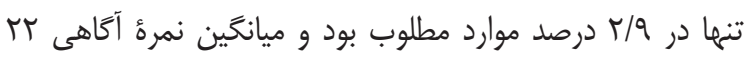

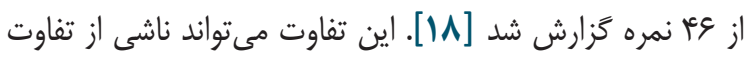




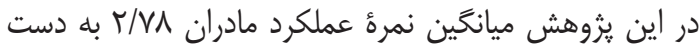
آمد كه عملكرد متوسط آنها رادر اين زمينه نشان مى دهد. عملكرد مادران در خصوص تعويض بلموقع يوشك پِ از هر بار دفع

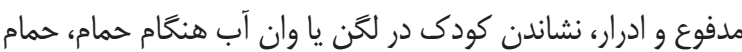
كودى با استفاده از دوش آب، شستن دستها قبل از شستوشوى كودى سنجيده شده است.

Jalali

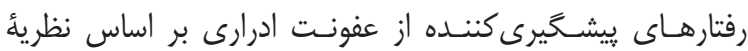

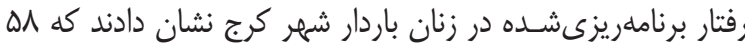
درصد از زنان عملكرد خوب در زمينأ يِيشَيرى از عفونت ادرارى

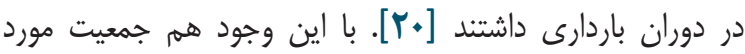

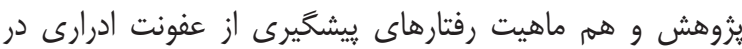
هردو يزوهش متفاوت است. نتيبحه كيرى

با توجه به نتايج بهدستأمده و مشخصشدن وضعيت پايئ آكَاهى و عوامل نخرشى مادران بر اساس تئورى رفتار برنامهريزىشده و رفتارهاى مادران از نتايج اين يزوهش بلعنوان نيازسنجى در

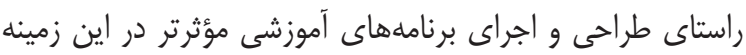
استفاده مىشود؛ جرا كه بررسى رفتارهاى ييشخَيرى كننده از عفونت ادرارى مبتنى بر مدل رفتار برنامهريزىشده با كمك به شناخت نيازهاى آموزشى مادران در اين زمينه براى حفظ سلامت كودكان

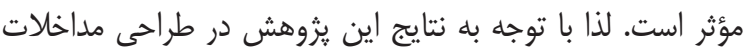
آموزشى بايد بر ميزان آكَاهى و سازء قصد رفتار بهعنوان مهممترين عوامل ييشبينى كننده رفتار مادران تأكيد شود.

\section{سباسَگزן ارىى}

اين يثوهش برگرفته از يايان نامئ كارشناسى ارشد آموزش بهداشت است كه با حمايت مالى معاونت محترم يزوهشى دانشگاه علوم يزشكى اراك با شماره ثبت ساري تصويب شده است. به اين وسيله از همكارى همةٔ اساتيد، كاركنان اين دانشگًاه و همجنين مادران شركت كننده در يثوهش تشكر مى كنيم. تعارض در منافع

هيج گَنه تضاد منافعى وجود ندارد.
در يخوهش Taghdisi و همكاران \/ V درصد (Vq نفر) زنان باردار در يزوهش براى ييشخيرى از عفونتهاى ادرارى از طرف خانواده راهنمايى شده بودند [19]. در يزوهش Hashemi Parast و همكاران نيز بر اساس مدل اعتقاد بهداشتى ميانگين نمره راهنماى عمل گروه آزمون قبل از

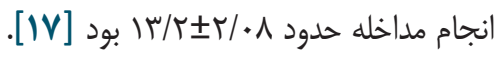
در اين يزوهش هنجارهاى ذهنى مادران در خصوص تأثيرگذارى

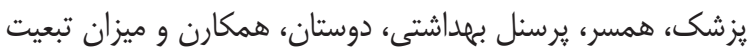
بيشتر يا انخَيزش ييروى مادر از اين افراد ديده شد. اين امر مىتواند ناشى از تفاوت در جمعيتهاى يزوهش باشد. بلَّونهاى كه در يثوهش Taghdisi نمونههاى مورد يزوهش از همسران و افراد خانواده خود تبعيت داشته و در اين بروهش مادران دختران زير دو موهي سال خود را براى يايش رشد به مراكز بهداشتى درمانى مىبردند و تماسهاى بيشتر آنها با يرسنل بهراشتى درمانى باعث شد تا اين افراد بلعنوان هنجارهاى ذهنى مادران معرفى شوند [19] .

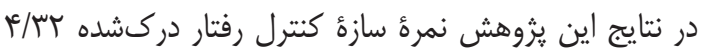
است كه توانمندى مادران را نشان مىدهد، ولى با اين وجود عملكرد مادران (T/VA) در خصوص بيشگيرى از عفونت ادرارى كودكان نشان مىدهد كه براى بالابردن سطح عملكرد مادران در اين زمينه بايد تلاش بيشترى شود. كنترل رفتار دركشده بهد بهد مادران در زمينةٔ انجام رفتارهاى ييشخَيرى با وجود خستخى مادر، هزينابربودن مراجعه به يزشك يا ضعف اطلاعاتى مادران در اين زمينه بوده است. لذا براى افزايش كنترل رفتار دركشده مادران و درنهايت تأثير آن بر انجام رفتارهاى ييشگيرانه روى موانعى همجون علاقهنداشتن مادر به انجام رفتار يِشخيرى يا كاهش

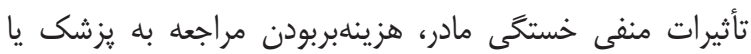
ضعف اطلاعاتى مادران در اين خصوص تأكيد مى شودد. در اين يزوهش قصد رفتارى مادران حدود F/D9 به دست آمد كه قصد مادر را براى انجام مراقبتهاى ييشگيرى از عفونت ادرارى كودى، شامل: نحوه شستوشوى كودى، تعويض يوشك لهـ و ساير رفتارهاى ييشگيرى، نشان مىدهد. اين امر نقطة قوتى براى احتمال گرفتن رفتار ييشگيرانه توسط مادر است. با اين وجود

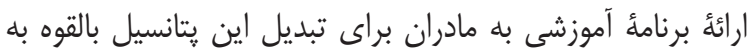
رفتارهاى بالفعل توصيه مىشود.

\section{References}

1. Nicolle LE. Uncomplicated urinary tract infection in adults including uncomplicated pyelonephritis. Urologic Clinics. 2008; 35(1):1-12.

2. Arabestani MR, Mahmoudi H, Alikhani M, Khosravi S. Evaluation Prevalence agents of urinary tract infection and antibiotic resistance in patients admitted to hospitals in Hamedan University of Medical Sciences 1391-92. Pajouhan Scientific Journal. 2014; 12(3):20-27.

3. Fesharakinia A, Taheri F, Saadatjo SA. Prevalence of Urinary Tract Infection in 7 Year Old Children 
in Birjand: Screening for Urinary Tract Infection in Children Before Admission to School?. Journal of Medical Sciences, Biomedical Pathology. 2005; 9(1):53-56.

4. Roberts KB. Urinary tract infection: clinical practice guideline for the diagnosis and management of the initial UTI in febrile infants and children 2 to 24 months. Pediatrics. 2011; 128(3):595-610.

5. Gaither TW, Cooper CS, Kornberg Z, Baskin LS, Copp HL. Predictors of becoming overweight among pediatric patients at risk for urinary tract infections. Journal of Pediatric Urology. 2018.

6. Mahyar A, Ayazi P, Azimi E, Dalirani R, Barikani A, Esmaeily S. The Relation between Urinary Tract Infection and Febrile Seizure. Iranian Journal of Child Neurology. 2018; 12(4):120126.

7. Gaither T, Cooper C, Kornberg Z, Baskin L, Copp H. Risk factors for the development of bladder and bowel dysfunction. Journal of Pediatrics. 2018; 141(1).

8. Hockenberry MJ, Wilson D. Wong's nursing care of infants and children [Shoghi M, Sanjari M, Persin trans]. 9th ed. Tehran: JamehnegarSaleme; 2011.

9. Dehdari T, Ramezankhani A, Zarghi A. Principles of health promotion. Tehran: Nazari publication; 2010 .

10. Shamsi M, Tajik R, Mohammad BA. Effect of education based on Health Belief Model on selfmedication in mothers referring to health centers of Arak. Arak Medical University Journal. 2009; 12(3):57-66.

11. McKenzie JF, Neiger BL, Thackeray R. Planning, implementing \& evaluating health promotion programs: A primer. Pearson; 2016.

12. Glanz K, Rimer BK, Viswanath K. Health behavior and health education: theory, research, and practice: John Wiley \& Sons; 2008.

13. Allahverdipoor H. Passing through traditional health education towards theory-oriented health education. Health Promotion and Education Magazine. 2005; 1(3):75-79.

14. Taylor D, Bury M, Campling N, Carter S, Garfied $\mathrm{S}$, Newbould J, et al. A Review of the use of the Health Belief Model (HBM), the Theory of Reasoned Action (TRA), the Theory of Planned Behaviour (TPB) and the Trans-Theoretical Model (TTM) to study and predict health related
سنجش سازههاى تئورى رفتار برنامهريزىشده (TPB) If.

behaviour change. London, UK: National Institute for Health and Clinical Excellence; 2006.

15. Sharma M, Romas JA. Theoretical foundations of health education and health promotion. Jones \& Bartlett Publishers; 2011.

16. Jalali M, Shamsi M, Roozbahani N, Kabir K. The effect of education based on the theory of planned behavior in promoting preventive behaviors of urinary tract infections in pregnant women. Journal of Jahrom University of Medical Sciences. 2014; 12(3).

17. Hashemi Parast M, Shojaizade D, Dehdari T, Gohari MR. Design and evaluation of educational interventions on the health belief model to promote preventive behaviors of urinary tract infection in mothers with children less than 6 years. Razi Journal of Medical Sciences. 2013; 20(110):22-28.

18. Baghiani Moghadam M, Shojaeazadeh D, Mohamadloo A, Fallahzadeh H, Ranjbary M. Evaluation of Preventive Behaviors of UTI Based on Health Belief Model (HBM) in Mothers with Girls Younger Than 6 Years Old. TB. 2013; 12(1):78-88.

19. Taghdisi MH, Nejadsadeghi E. The effect of health education based on health belief model on behavioral promotion of urinary infection prevention in pregnant women. Journal Research \& Health. 2012; 2(1):44-54.

20. Jalali M, Shamsi M, Roozbehani N, Kabir K. Preventive behaviors of urinary tract infection (UTI) based on the theory of planned behavior among pregnant women in Karaj in 2013. Daneshvar. 2014; 21(108):59-66. 